\title{
The Quantity and Quality of Teachers' Self-perceptions of Read-Aloud Practices in Norwegian First Grade Classrooms
}

\author{
Anne Håland ${ }^{1}$ (D) . Toril Frafjord Hoem ${ }^{1}$. Erin Margaret McTigue ${ }^{1}$
}

Published online: 23 March 2020

(c) The Author(s) 2020

\begin{abstract}
Read-alouds are a frequent practice in early childhood classrooms and provide great potential for developing literacy skills for young learners including vocabulary, comprehension, text structure awareness, visual literacy, and fluency. Yet, any potential benefit of read-alouds depends on how the teacher enacts a read-aloud, particularly in regards to the amount and type of talk that surrounds the practice. Despite frequent use, read-alouds have not been systematically considered in Norwegian early childhood classrooms, which is the goal of this study. Specifically, 299 first-grade teachers completed a survey on read-aloud practices in December, as well as provided information on the most recently read-aloud texts in both December and May. Quantitative results were analyzed descriptively while qualitative results were analyzed via open coding. Findings indicate that read-alouds are most used as a tool for engaging and managing students rather than as a formal instructional practice. As read-alouds most typically occurred during lunch time, texts were selected primarily for entertainment and teacher talk occurred most frequently for the purpose of defining words. Conversely, teachers reported comparatively minimal use of planned (instructional) stops and reported limited focus on literacy elements. The analysis of book choices indicated that teachers used few informational texts and frequently relied on older, well-known children's literature. Implications for this study are that although read-alouds provide much potential benefit for young learners' literacy development, Norwegian teachers could capture underutilized benefits of this practice through greater planning and intentionality.
\end{abstract}

Keywords Read-aloud · Literacy · Early childhood · Book selection · Children's literature · Qualitative · Quantitative

\section{Introduction}

The benefits of interactive read-alouds have long been recognized as one avenue to both early and future literacy success (National Early Literacy Panel 2008). Reading aloud has been highly recommended for encouraging language and literacy development (Anderson et al. 1985), and many elementary school teachers report that they use read-alouds daily (Lehman et al. 1994; Lickteig and Russell 1993; McCaffrey and Hisrich 2017). This practice has the potential to contribute to children's literacy development in many ways, including comprehension, text-structures, vocabulary, and visual literacy (Serafini and Moses 2014). To maximize the effectiveness of read-alouds for enhancing children's language and literacy, teachers must invite

Anne Håland

anne.haland@uis.no

1 National Centre for Reading Education and Research, University of Stavanger, Stavanger, Norway the children to talk about the texts before, during, and after read-alouds (Beck and McKeown 2001). The quality of readalouds varies across classrooms (Kindle 2011; Pentimonti and Justice 2010), and some teachers view read-alouds as primarily entertainment and not instruction (Lickteig and Russell 1993; McCaffrey and Hisrich 2017). Furthermore, when teachers expect students to listen quietly throughout the read-aloud (Lickteig and Russell 1993), they cannot fully utilize the endemic instructional opportunities.

The purpose of this descriptive study is to document teachers' read-aloud practices and attitudes in Norwegian first grade classrooms and to analyze the ways in which these practices align with research-based recommendations. We focused on first grade for several reasons: First, because children at the age of 6 can comprehend texts at a higher level than they can formally decode on their own. Secondly, because comprehension strategies potentially modeled in interactive read-alouds, mirror those suggested by decontextualized research for older readers, but can occur in a developmentally appropriate manner (Smolkin and Donovan 
2001). Furthermore, typical first grade reading instruction, such as letter knowledge, can be connected to authentic texts via print referencing (Zucker et al. 2009). To best reflect authentic classroom practices, in our literature review and our survey questions, we focused on teachers reading to a whole class, rather than reading to a small group. Although children's literature serves a prominent role in early education in Norway, to date, no research has systematically considered read-aloud practices in first grade. This study focuses on the quantity and quality of teachers' read-aloud practices occurring in Norwegian first grade classrooms. The findings are based on a survey of 299 teachers. This survey covers the topics of (1) Frequency of read-alouds, (2) Rationale for text selection, and (3) The extent that read-alouds are embedded in talk around the texts.

In the introduction, after presenting a brief background information of the Norwegian context for this project, the benefits of teachers' interactive read-aloud, and how to reach those benefits are highlighted. Next, the teachers' responses to the survey questions are presented. Third, it is discussed to what extent, and in what manner the teachers' read-aloud practices are connected to research-based recommendations.

\section{The Norwegian Context}

Norwegian teachers follow a national curriculum (Ministry of Education and Research 2006), which influences their choice of literature in language arts (referred to as "Norwegian"). Earlier curricula in Norwegian have had a clear national anchoring, with an intention to introduce students to a Norwegian cultural heritage. Literature written by Norwegian authors representing a national literary canon, was listed in the curricula. However, in the current curriculum (The Knowledge Promotion), the Norwegian subject has been repositioned as a multicultural subject adapted to a society with a high degree of diversity (Ministry of Education and Research 2006). As such, cultural heritage is no longer emphasized as something that has to be transferred to new generations. Instead, cultural understanding, identity development and cultural diversity are prioritized. Students are expected to read and listen to diverse texts (Norwegian as well as translated) for different purposes. Although talking about texts is integrated into the curriculum via competence aims such as "discuss characters and plot in fairy tales and stories, discuss the content and form of old and new songs, rhymes and poems," (Ministry of Education and Research 2006, online English version, no pagination), there are no specific guidelines in the curriculum for teachers to focus read-alouds as a point of departure for the text-talks towards those aims. However, as first graders are not yet able to decode more complex texts, read-alouds are a natural way of giving them access to the literature.

\section{Benefits of Interactive Read-Aloud Practices in Elementary School}

Interactive read-aloud sessions provide many benefits for both exploring the world and for literacy development in elementary school. It is essential for young readers to identify as readers and writers to explore the world. Smith (1988) refers to the concept of belonging to a literacy club. Teachers, who encourage children's participation in interactive reads aloud, can influence children's self-perceptions and identities as readers (Wiseman 2012), transmit the pleasure of reading (Richardson 2000), and promote children's interests in books (Galda and Cullinan 1991), and thereby expand the literacy club.

Providing different types of literature to young students in read-aloud sessions can offer a better understanding of oneself and others by offering insights into people with unique lives. Nussbaum (2010) calls this a narrative imagination, which involves the ability to feel other person's emotions, wishes, and desires. Also, read-alouds by teachers give students access to cultural capital regardless of their ability to read or their home literacy environment (Cazden 1992; Heath 1983), and can therefore offer students from all social classes access to an elaborated code (Bernstein 2000 [1996]).

High expectations and challenging reading activities can motivate students to learn (Powell et al. 2006), whereas lower expectations coupled with traditional instruction focusing on decoding, can lead to disengagement and frustration (Wiseman 2012). When teachers read more challenging texts aloud, children can be engaged with ideas above their reading level by being exposed to larger themes and constructs, such as scientific inquiry (Heisey and Kucan 2010). Reading texts on topics that students have a strong interest in, can increase motivation for learning (Jobe and Dayton-Sakari 2002), especially with informational texts, because young children often show natural interest in such texts (Maloch and Horsey 2013).

Finally, teachers reading aloud can stimulate students' literacy development, at early and later stages. Readalouds, particularly interactive ones, promote oral language (Mol et al. 2009; Snow and Ninio 1994), and allow students to experience decontextualized language (Heath 1983; Snow and Dickinson 1991). Connected to decoding skills, read-alouds can stimulate phonological awareness (Stadler and McEvoy 2003), print awareness (Justice and Ezell 2002; Mol et al. 2009; Zucker et al. 2009), phonemic awareness (Murray et al. 1996), and letter recognition (Bus et al. 1995). For emergent reading skills, the research draws upon both one-to-one situations (e.g., lap reading) and whole class settings. As such, Zucker et al. 
(2009) could be recommended for guidelines of how to enact these practices in a whole-class read-aloud.

Transitioning to more advanced skills, interactive readalouds can also offer an understanding of story structure, syntax and grammar (Stevens et al. 2010), promote development of narrative competencies (Kamberelis 1998) and function as a model text for students' own writing (Bradley and Donovan 2010; Graham et al. 2012). Many research studies that involve read-alouds, center on the benefits of developing comprehension strategies and vocabulary (Brabham and Lynch-Brown 2002; Santoro et al. 2016; Silverman et al. 2013; Smolkin and Donovan 2001). Finally, interactive read-alouds can be a vehicle for building children's content knowledge (Heisey and Kucan 2010; Strachan 2015) and stimulate disciplinary literacy learning and deeper comprehension of a text by offering access to different discourses, in language art (Kamberelis 1998), math (Anderson et al. 2004), natural science (Leung 2008; Mantzicopoulos and Patrick 2011; Varelas and Pappas 2006), and social science (Strachan 2015), and by offering focused, high-quality discussions (Shanahan et al. 2010; Wright and Gotwals 2017). Teachers can also promote critical thinking through posing questions (Meller et al. 2009), especially if the selected books are addressing social issues of interest or importance to children.

\section{Teachers' Implementation of Read-Alouds}

Children will not adopt literacy behaviors simply because they hear stories. Teachers' thoughtful choice of books, the ways in which the books are shared and the nature and quality of interactions during the teachers' read-alouds, may open or close learning opportunities to use language for a wide range of purposes (Lennox 2013). To deepen and extend the children's content knowledge, vocabulary, concepts of text structures etc., teachers have to plan the readalouds carefully (Bingham et al. 2017).

Fisher et al. (2004) examined expert teachers' read-aloud practices to identify common factors. First, teachers have to select books, which are appropriate to students' interests and matched to their developmental, emotional, and social levels. Because the ability to understand various types of texts is vital to the process of becoming a proficient reader, the repertoire should include a variety of well-illustrated, quality literature: such as fiction, poetry and information books (Duke 2000; Kamberelis 1998; Lennox 2013; Pentimonti et al. 2011). Despite evidence that young children enjoy informational texts and are capable of engaging with them in stimulating ways (Duke 2000; Kraemer et al. 2012), primary classrooms tend to neglect the reading of factual prose (Duke 2000; Pentimonti et al. 2011; Price et al. 2012; Smolkin and Donovan 2003; Yopp and Yopp 2012). If children are primarily exposed to narrative structure, they will develop a strong schema for reading narration, but may under-develop strategies for informational texts (Kamberelis 1998).

Teachers also need to establish a clear purpose for a readaloud session (Fisher et al. 2004). As stated above, readaloud sessions can develop different aspects of literacy, and the purpose can vary on a continuum from phonological awareness to disciplinary literacy. The purpose could also be social, connected to self-identification or empathy. Reading for enjoyment is, of course, also a valid reason for readalouds (Fisher et al. 2004). Regardless, the students should understand the purpose(s) of the activity.

Next, the teacher ought to preview and practice the text to be able to model fluency and read the text with clarity and expression (Fisher et al. 2004). The teacher's voice is the vehicle that conveys the text in a way that enables students to develop personal images and responses. If teachers have practiced the read-aloud, they will better be able to use expression to engage listeners. If teachers are unfamiliar with the texts, they might easily mispronounce words, stumble, or emphasize parts of sentences that alter the meaning.

Teachers should also anticipate and plan for pauses for think-alouds or interactive elements (Fisher et al. 2004). Thoughtfully planned interactive elements provide the necessary support as children encounter difficult content, different text features, or challenging vocabulary (Cummins and Stallmeyer-Gerard 2011; McClure and Fullerton 2017). Researchers agree that the most valuable aspect of read-alouds, is not the narration, but rather the talk that surrounds the reading (Heath 1983; Snow and Ninio 1994). To engender such talk, one has to focus on important ideas and invite students to reflect rather, than expecting quick answers (Teale and Martinez 1996). However, such opportunities occur more often when planned than left to spontaneity. Otherwise, one is likely to ask questions on a surface level, such as clarifying content or unfamiliar vocabulary, or by involving the children in the ongoing story by asking them to simply summarize what they just heard (Beck and McKeown 2001). Sandora et al. (2016) argue that stopping to discuss smaller segments of texts (distributed discussion), rather than waiting until having read the entire text, can better facilitate students' comprehension and provide richer opportunities to reflect on events and ideas, clarify misconceptions, and grasp subtleties implied in the text. Teachers can engage students in reflecting on meaning "within the text," "about the text," or "beyond the text" (Fountas and Pinnell 2018). Open-ended questions should encourage students to explain text ideas, incorporate background knowledge based on the information in the text and reduce surface association (Beck and McKeown 2001). An important component can be found in follow-up questions (Gibbons 2002), meant to scaffold students' thinking by using their initial response to form new questions that encourage elaboration 
and development of ideas. Furthermore, beyond questioning techniques to increase comprehension and oral language development, during an interactive read-aloud, teachers can foster opportunities for students to turn and talk to partners (Drogowski 2008), or guide children to think collectively in small groups to construct meaning (Pantaleo 2007).

Finally, ideally, teachers should plan for independent reading or writing to align the read-aloud with further literacy instruction (Fisher et al. 2004). Depending on the purpose of the reading, children could be invited to write texts with similar text features as the text they have just heard (Bradley and Donovan 2010), or writing text responses to reflect on aspects of the text (Cummins and StallmeyerGerard 2011). In summary, to maximize the read-aloud experience, teachers must view this time as an intentional and valuable component of their literacy instruction.

\section{Method}

\section{Design and Data Sources}

The purpose of this study was to extend knowledge of first grade teachers' read-aloud practices and teacher cognition around this practice. The study was embedded within a larger randomized control trial (RCT) regarding the impact of teacher density and professional development on literacy instruction (Solheim et al. 2017), for which first-grade teachers were surveyed twice on different aspects of their literacy practices (December and May). The source of data for this study, an online teacher questionnaire $(n=299)$ regarding teachers' read-aloud practices, was comprised of both closed and open-ended questions. The closed questions allowed us to capture how teachers described their practices. The open-ended questions, regarding the books most recently read-aloud, provided an opportunity to analyze a corpus of text and consider how the selected texts were in alignment with teacher practices. All data collection with participants followed ethical guidelines.

\section{Participants}

Three hundred classrooms from 150 schools, nested within 53 Norwegian municipalities participated in this study. Two first grade teachers from each school answered the questionnaires, resulting in a sample of 300 first grade teachers, although 299 completed the full surveys. Approximately 97\% $(n=289)$ were female, with $13 \%$ being 29 years old or younger, $24 \%$ were $30-39,34 \%$ were $40-49,28 \%$ were $50-59$, and $7 \%$ were over 60 years old. Most of the teachers (68\%) held a bachelor's degree in education, although $27 \%$ also had a master's degree, while $5 \%$ had three years or less of university study.

\section{Survey Instrument}

To provide context, teachers first responded about the frequency of read-alouds and the classroom context. Specifically, teachers answered questions regarding (a) book selection rationale, (b) the type of talk occurring within read-alouds, and (c) instructional focus during read-alouds. The format and question stems were adapted from the PIRLS survey on reading practices (Hooper et al. 2015).

Content was derived from both experiential knowledge and empirical research. For example, the question about when, during the school day, teachers typically read to children, was derived partially from observations that many teachers use read-alouds to entertain children at lunch. The question concerning use of spontaneous or planned stops for talking or read first then talk, was inspired by Beck and McKeown (2001) and Sandora et al.'s work (2016). Next, via open-ended questions, inspired by Yopp and Yopp (2006), teachers responded to: (a) What was the last book that you read aloud?, and (b) Why did you choose this book?

The questionnaire was initially piloted by 20 first grade teachers and revised for clarity. The final questionnaire was comprised of 15 Likert scale items. Inter-item reliability on this sample $(n=299)$, measured by Cronbach's $\alpha$, was 0.73 , indicating acceptable reliability.

\section{Data Collection}

The questionnaires were distributed via email in midDecember and mid-May. Because there is such rapid growth in literacy skills in first grade, we reported the Likert questionnaire results from mid-year, anticipating it would better represent teachers' practices throughout first grade, rather than reflecting their end-of-year practices. Additionally, we report the frequency of reading question and the open-ended questions (regarding the most recently read book) and from both mid-year and end-of-year.

\section{Data Analysis: Quantitative}

Using SPSS software, the survey questions were analyzed descriptively by frequency. Results were presented visually.

\section{Data Analysis: Qualitative}

The open-ended questions were analyzed qualitatively, with the first and second author using an inductive approach so that codes emerged from the data (Lincoln and Guba 1985). The qualitative analysis occurred in five stages: organizing, coding, generating categories, testing emerging categories, and searching for alternative explanations (Marshall and Rossman 2014). Specifically, regarding the teachers' rationale for book selection, after a first review of the data, broad tentative categories 
were identified. Using these broad categories, the first and second author re-analyzed the rationale for book selections individually. In this second analysis, additional categories emerged. Third, the authors individually analyzed the reported answers with the finer-grained categories. Finally, for triangulation, results were cross-checked within the researcher group.

For coding the books, overall categories were outlined based on three common genres: (a) literacy-instruction focused, (b) content area focused, (c) social focused, and the first and second authors individually categorized the texts. Results were compared and differing results discussed until reaching consensus. When a book could be placed in more than one category, a primary category was selected. During this process, categories were split or new categories were created as needed. For example, the data collected in December, resulted in many book choices being related to a holiday theme. $1 \%$ of the books were not possible to code according to rationale.

Books were also coded based on their date of publication with two categories, choosing the millennium as a turning point between newer books and classic/older books. Genres were divided into two categories: fiction and factual books. $10.9 \%$ of the books were not possible to define according to date of publication, because the titles were not precise enough (e.g., fairy-tale, book about insects), but all the books were possible to code according to genre.

\section{Integrating Findings}

After both the qualitative and quantitative results were analyzed, the findings were integrated or mixed into overarching patterns. For example, the context of frequently enacting read-alouds at lunchtime, was connected with teachers selecting books for the purpose of entertainment. As such, we inferred that read-alouds often serve as a management tool to entertain students during non-academic times of the school day.

\section{Results}

Within the results section, we first present the contextual data (frequency, context of read-alouds). Next, we present the teachers' book selections and their specific rationale for those books. Finally, we present the survey results regarding teachers' general practices in book selection and read-aloud practices.

\section{How Often Do First Grade Teachers Engage Their Students in Read-Alouds?}

In mid-year first grade, read-alouds represented a frequent practice, with over half (55.2\%) reading aloud every day or nearly every day, $39.1 \%$ at least once or twice a week, and $5.4 \%$ reported once or twice a month. At the end of the school year, about half of the teachers $(50.7 \%)$ read aloud every day or nearly every day, $41.9 \%$ read at least once or twice a week, and $6.4 \%$ read once or twice a month. These findings suggest a stability of practice across the year.

\section{When, During the School Day, Do Teachers Typically Read to Children?}

As shown in Fig. 1, 56.4\% of the read-alouds occurred during lunch breaks $32.6 \%$ occurred during Norwegian lessons, while $11.1 \%$ occurred during other lessons.

\section{What is Most Important for Teachers When Selecting Texts to Read Aloud?}

Teachers rated six dimensions potentially important to text selection on a Likert scale. Results are displayed in order of importance, by percentage, in Fig. 2.

\section{Topic}

The entertaining nature of the texts was clearly of high importance to teachers, with $57.4 \%$ rating that as very important and $42.3 \%$ rating it as quite important. This finding suggests that teachers may view teachers' read-alouds as a source of entertainment.

Regarding topic, specifically, if a text addressed an important issue for children, this was a priority, but not teachers' highest priority. Specifically, only $19.1 \%$ reported that this was very important. However, $63.4 \%$ reported that this was a quite important characteristic. In total, $17.4 \%$ of teachers rated this as less important or not important. It is important

\section{When Read Alouds Occur in First Grade School Days}

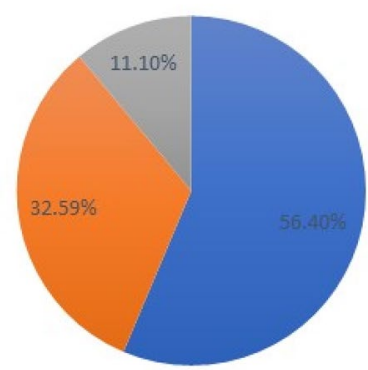

- Lunch Break №rwegian Lessons = Other Subject Lessons

Fig. 1 First grade teachers' reporting as to when read-alouds occur in the school day 


\section{First Grade Teachers' Response: When Reading Aloud, how important is it that a} book ...

70

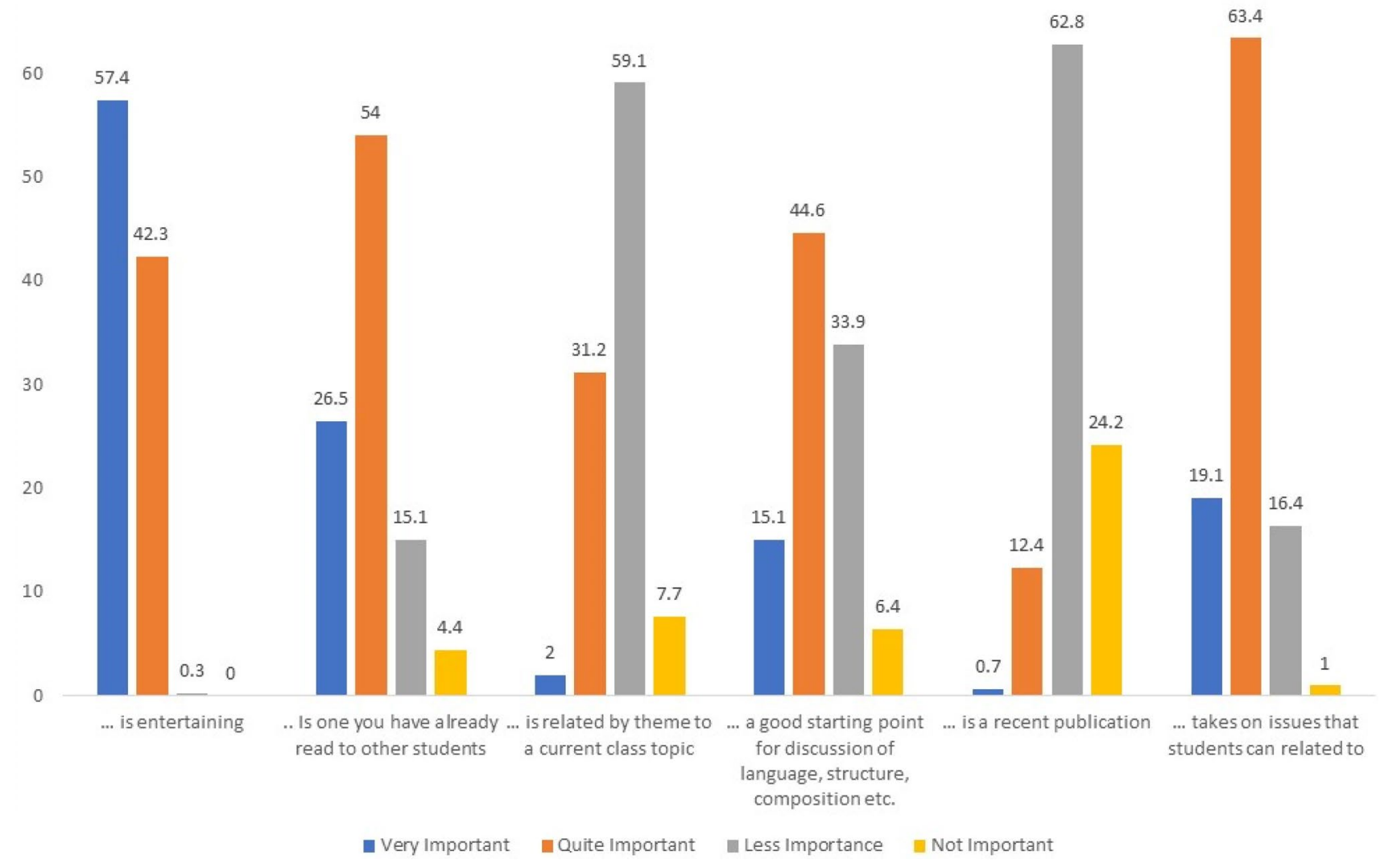

Fig. 2 First grade teachers' report on criteria used for book selection for read-alouds

to note that these two findings may interact with each other because books that address issues relevant to students are typically more serious in nature than those written to entertain.

Of even lower priority, were issues related to whether books were either a good starting point for discussion regarding language, structure, and composition (only $15.1 \%$ of teachers considered this as very important) or related to a current class theme or topic (only $2 \%$ considered this very important). This provides additional evidence that read-alouds may be considered first and foremost as a form of entertainment, rather than being fully integrated into the curriculum.

\section{Familiarity}

Regarding teachers' tendency to select known books (which may favor classics), we looked at their ratings regarding if they have already read that book to children and feel assured that it will be well received. The majority of teachers $(80.5 \%)$ rated this dimension as quite important or very important. This finding may also be related to an emphasis on texts being entertaining. Conversely, when asked about how important it is for a book to be recent, we can see that teachers did not prioritize this dimension, with less than one percent of teachers rating this as very important. When taking these two results together, they indicate a trend towards reading a consistent set of texts rather than introducing students to new authors.

\section{Recent Selections}

To take a snap shot into the current practice and look for coherence between reported practice and actual practice, we therefore asked two open-ended questions concerning book selection and rationale for it. The teachers were asked to mention the latest book they had read, and the reason for choosing that book. These results were analyzed qualitatively. The books were divided into two categories based 
on year of publishing (before or after millennium), and also divided into two categories according to genre (fiction or non-fiction). The results from both mid-term and end of school year showed that teachers tend to use old books (302 titles) to newer books, (231 titles), and they used a limited variety of genres with a clear dominance of fiction. Many canonized authors, (e.g., Roald Dahl, Astrid Lindgren, Thorbjørn Egner, Alf Prøysen), who were prominent in the previous curriculum, were represented. Only 10 out of 533 titles (3\%) were factual books (e.g., books about seasons, animals, and insects). These results support the findings in which teachers did not prioritize selecting texts related to a current class topic (see Fig. 2).

Answers from the open-ended question concerning rationale for book selection were categorized into seven categories (content or subject focused, related to literacy instruction, amusement, recommendation, appropriateness, ad hoc, unmarked) and displayed in Fig. 3. Books selected because of theme, time of year, cultural heritage, or class environment, were categorized as "content and subject related". Answers like, "The book was about Christmas", and "To teach minority students about trolls and Norwegian tradition/culture", were typical quotes in this category. Selecting books as model texts, for letter instruction, for interpretation, or to practice reading strategies, were coded as "literacy instruction". Answers like "The students make their own books on Ipad. Fairytales are used as an inspiration" and "We talked about Rhyme and the letter R" are examples of answers in this category. Books described as funny, exciting, humorous, or "students like it", were coded as "amusement". Examples of answers in this category include: "A lot of amusing events in the book that are both funny and exciting." and "Nice book to read aloud for the pupils. They like the story." The category "recommendation" included students' own choices or books recommended by adults. Typically teachers in this category said something similar to the following: "The book was recommended by a colleague", "The book was recommended by the school librarian", or "One of the pupils brought it from home and wanted us to read it". The category "Appropriateness", included books the teachers reported having previous experience with, or books that had appropriate text length, or were especially suitable for the age group, situation, level, easy to understand. Quotes like "I like these books, know them very well and have good experience reading them" and "Texts that are appropriate for the age group, big pictures and suitable chapters" were typical answers in this category. The "Ad hoc" category included books that were selected randomly. An example of this category was: "During lunch I often read books randomly chosen." Finally, $1 \%$ of the rationales were unmarked or could not interpreted.

As shown in Fig. 3, the teachers reported content and subject as the most important rationale for the choice of book (e.g., it's Christmas, we work with fairy-tales, friendship, Roald Dahl author study) both at mid-term content $(56 \%)$ and at the end of school year $(32 \%)$. The mid-term result was influenced by the proximity of the Christmas holiday and many titles suggested Christmas content. At end of school year, the results suggested a shift from midyear, with a greater emphasis on theme for selecting books. Amusement, appropriateness, and recommendations from others were reported as being twice as much of a rationale for choosing book than was literacy instruction (9\% midterm and $12 \%$ at end of school year), suggesting a stability of practice and aligned with the survey results.

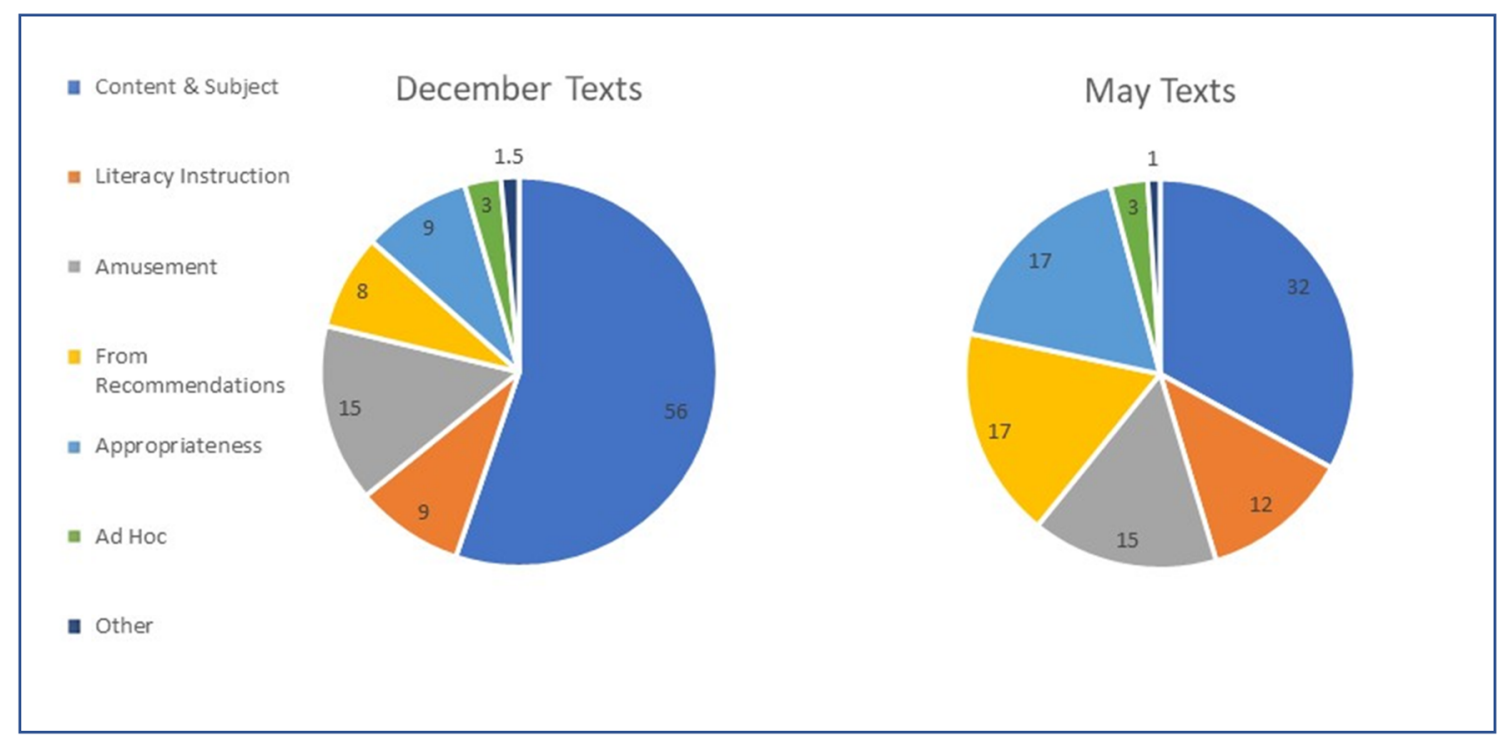

Fig. 3 Categories of texts selected for read-alouds in December and May of Grade 1 


\section{Type of Stops for Talking that Teachers Make During Read Alouds}

Very Often or Always

- Sometimes or often

- Seldom or Never

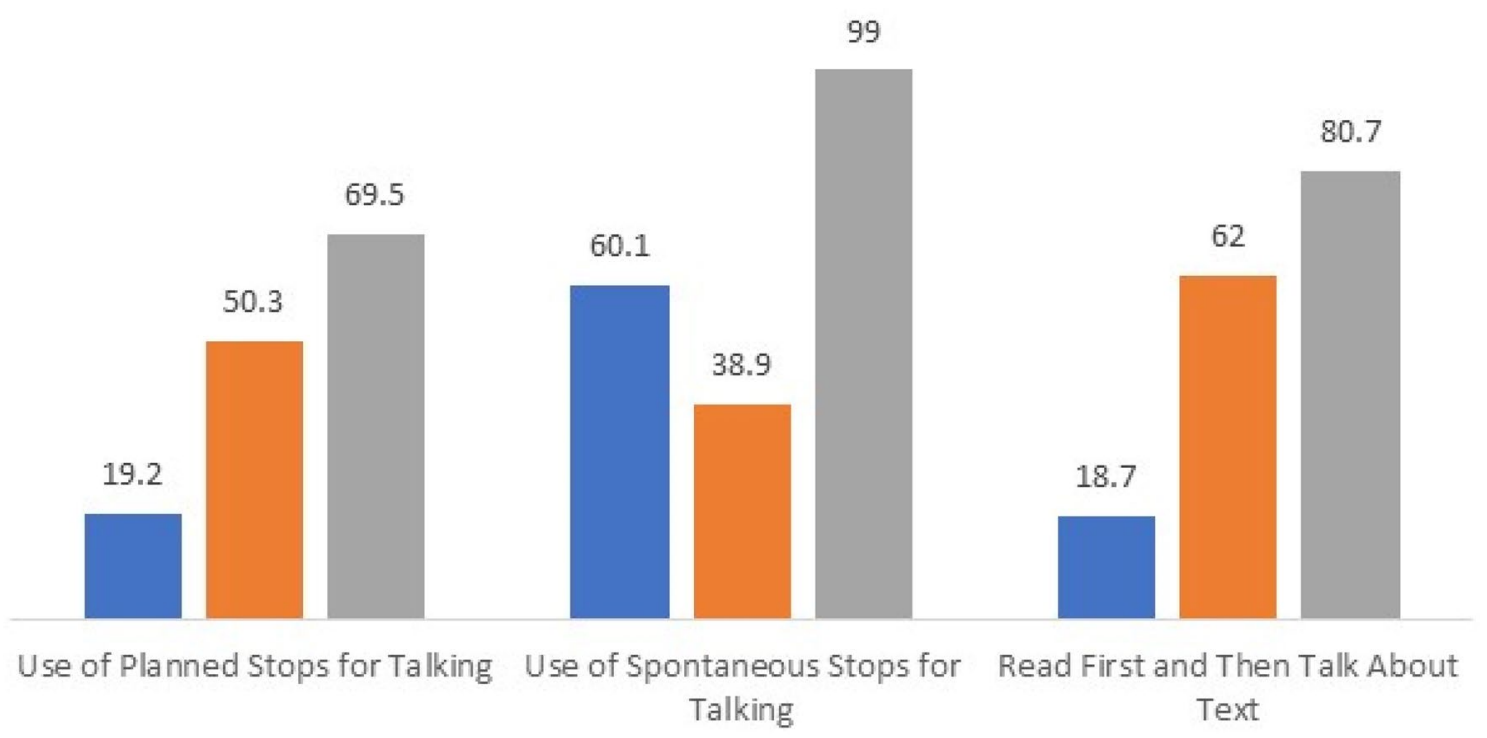

Fig. 4 Type of stops for talking that teachers make during read-alouds

\section{To What Degree do Teachers Provide Time to Talk During Read-Alouds?}

Due to much evidence that the talk surrounding read-alouds is valuable for student learning (Beck and McKeown 2001; Fisher et al. 2004), we specifically analyzed this aspect of teacher practices. Our first piece of evidence regarding teachers' attention to the "talk" that surrounds read-alouds, regards asking teachers about the extent that they place value on a book being a good starting point for discussion (see Fig. 2). Only $15 \%$ of teachers rated this as very important, while most (44.6\%) rated this as quite important. Whereas, a combined $40.3 \%$ considered this to be of less importance or not important. Such results indicate that this is not the primary lens through which teacher select texts.

Next, we inquired specifically into instructional practices. Regarding the practice of pausing and talking during the book, teachers reported frequent use of this strategy. Specifically, $60.1 \%$ reported always or very often stopping spontaneously for talking. 38.9\% reported stopping sometimes or often (see Fig. 4). This indicates that conversation does surround the read-aloud.
However, the use of planned stopping points during readalouds, was far less widely reported. In total, less than half of teachers (19.26\%) reported very often or always planning stopping points. In contrast, half of teachers used planned stops sometimes or often, and $30.5 \%$ engaged in planned stops seldomly or never. This indicates that read-alouds may be considered an informal teacher practice - one that may not be planned for in a systematic manner, like an instructional sequence would be.

Regarding reading first and then talking about the text, fewer teachers $(18.7 \%)$ followed this model very often or always, but $62 \%$ reported using the approach sometimes or often. This finding, taken in conjunction with teachers' reports on spontaneous and planned stops, indicates that talk was often interspersed with the read-aloud, and often occurred at the end of the read-aloud as well.

\section{What Type of Practices do Teachers Engage in During Read-Alouds?}

Finally, we inquired about specific practices that teachers may report concentrating on during read-alouds (see Fig. 5). 


\section{Instructional Focus/Practices During Read Alouds with First}

\section{Graders}

घ Very Often or Always a Sometimes or Often Never or Seldom

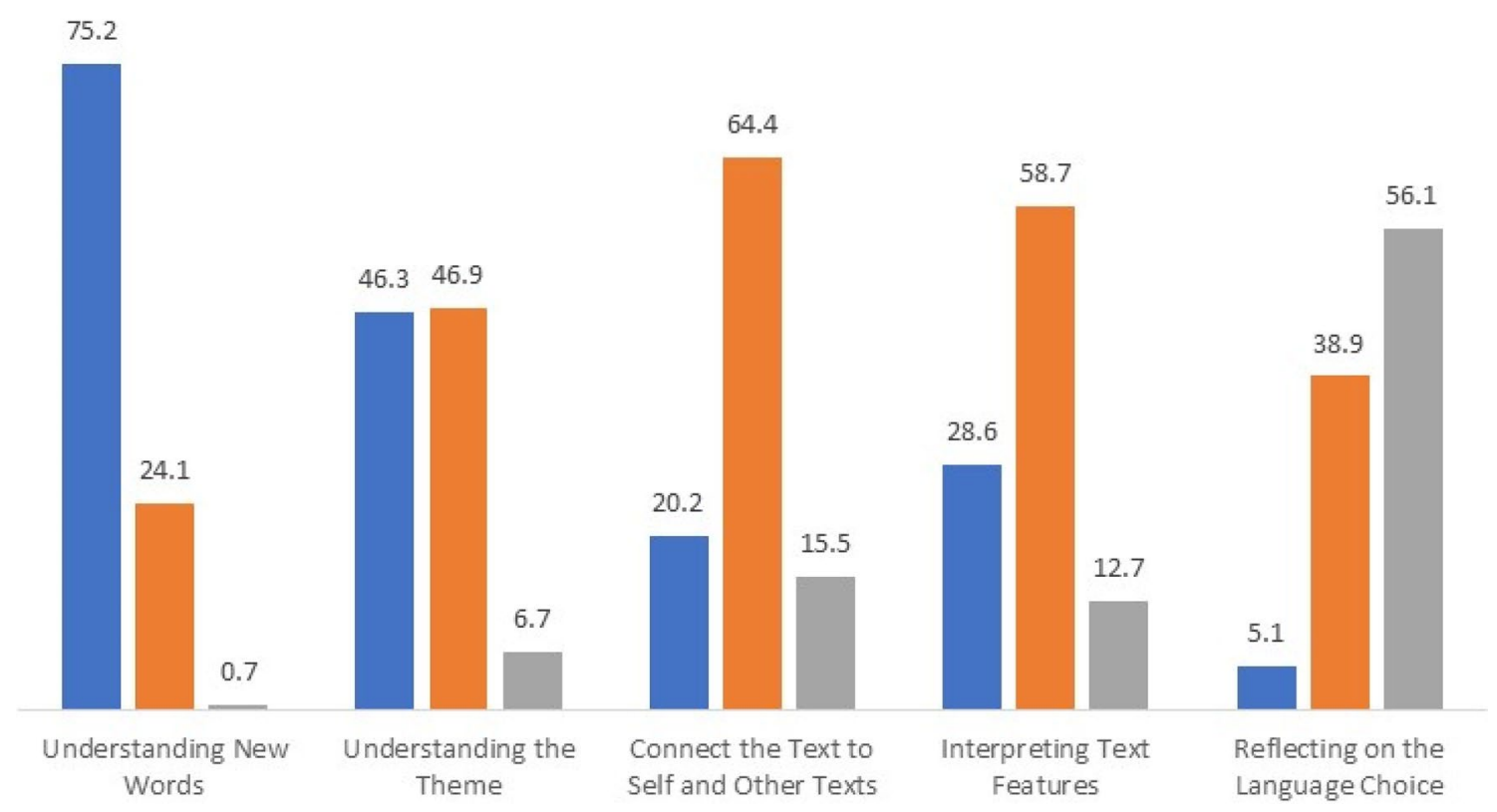

Fig. 5 Instructional practices and foci of first grade tachers during Read-alouds

From these data sources, we can see that teachers were particularly focused on texts as a source for learning new words when they read aloud. Teachers also emphasized that children should understand the theme or a life lesson derived from the text, suggesting that teachers aim for students' understanding to go beyond basic comprehension and plot sequence. In contrast, strategies connecting the text to students own life or other texts (which encourages students to more directly engage with the text), were less frequently used. This would suggest that the read-alouds may have a teacher-centered nature. Finally, the focus of the discussion tended not to extend to the craft of writing. For example, although teachers drew students' attention to new words, teachers less frequently prompted them to reflect on text features (28.6\% very often or always) or the author's language choice $(5.1 \%$ very often or always).

\section{Discussion}

This study draws upon previous findings that underline how teachers' reading aloud practices can contribute to students' literacy development (Serafini and Moses 2014). To summarize, in line with international reports (Lehman et al. 1994; McCaffrey and Hisrich 2017) the quantitative data indicates that Norwegian first grade teachers report using read-alouds quite often, although more during lunchtime than during instructional periods. When selecting a book to read, entertainment was rated with highest importance, while recency of publication was rated of the lowest importance. The qualitative data, regarding recently read titles, supported the survey data regarding the selection of books. The teachers tended to favour classic, older titles instead of new books, and amusement was of high importance. Both data sources indicate that the selection of books was often related to the topic, but rarely to literacy skill instruction (e.g., comprehension, writing). During read-alouds, teachers reported frequent use of spontaneous stops, to define or clarify new words, but placed much less emphasis on the planned stops which are central to interactive read-aloud. The findings stresses both potential and unused potential for literacy learning in the read-aloud practice with first grade students. In the final section, these practices are discussed in light of researchbased recommendations.

\section{Read-Alouds: Frequency, Selection, and Source of Words}

A practice where teachers read aloud to students as a daily or weekly routine, gives rich potential to invite students to be 
members of the "literacy-club" (Smith 1988). This practice also offers access to a cultural heritage and an elaborate code (Bernstein 2000 [1996]; Cazden 1992), and can contribute to equalizing social differences related to cultural capital. In a segregated society, this practice is also important because it gives children a common frame of reference. This frequent use of teacher read-aloud also align with research based recommendation of a daily class practice (Zucker et al. 2009), regarding stimulating children's interests for books (Galda and Cullinan 1991) and communicating a pleasure for reading (Richardson 2000).

The teachers reported selecting books that they had reason to believe would be well received, and felt confident in their ability to select entertaining books. The open-ended questions indicate that many teachers encouraged children to bring their own books to school to be read aloud (See the category "recommendation" in Fig. 3), and in that way acknowledged and honored the children's own taste of books. Such practices of selecting books appropriate to students' interests and matched to their emotional and social development are recommended by researchers (Fisher et al. 2004), and a common rationale amongst our teachers. The finding that it is quite important for teachers to select books that take on issues that students relate to, suggests that teachers may view read-alouds as a source for self-knowledge and empathy (Nussbaum 2010).

Aligned with best practice, is the finding that teachers also used texts as source to help students learn new words (Brabham and Lynch-Brown 2002; Santoro et al. 2008). The teachers reported that they very often stopped during reading to clarify words that might be difficult to understand, and thus attempted to enhance the children's vocabulary knowledge in an authentic manner. Interactions during reading are key to facilitating word acquisition from read-alouds in the early elementary grades (Brabham and Lynch-Brown 2002; Sandora et al. 2016). Spontaneous stops were reported as more common than preplanned stops, showing that the teachers are responsive in the moment, monitor comprehension, and work to secure comprehension in the immediate situation.

\section{Read-Aloud-Not an Integrated Part of Literacy Instruction}

Previous research has demonstrated how interactive readaloud practices can contribute to a wide set of literacy components that are essential in students' literacy development-from letter recognition (Bus et al. 1996) to comprehension strategies (Santoro et al. 2008). However, while the emphasis on a narrow repertoire of texts (i.e., entertaining), lunchtime reading, and spontaneous stops may support reading motivation, the pattern of practices do not reflect a planful and intentional literacy instruction which would systematically support literacy development (Bingham et al. 2017; Fisher et al. 2004).

Clearly, it is hard to utilize the full potential of readalouds if they are not an integrated part of school subjects, but are instead typically situated in a break, like lunchtime. In Norwegian classrooms, children typically bring their own food to school and eat in their classroom. Therefore, teachers' main responsibility during lunchtime is to ensure that students eat their food. As such, the purpose of reading while the students eat is primarily to make sure that students are quiet, settled and focused on their meal. In this sense, teachers' read-alouds are more related to managing students' behavior and have little connection to developing literacy skills. In fact, such a context creates a situation in which students are supposed to listen quietly, rather than actively engage in the read-aloud (Lickteig and Russell 1993).

In addition, the findings suggest that the selection of text genres are influenced by the lunchtime context, during which Norwegian first grade teachers emphasize reading for amusement. Besides eating, it is likely that the teachers want to create a school break, and make lunchtime a fun and social setting. Again, in this context, the teachers' readaloud sessions serve a quite different purpose than developing literacy.

In contrast, according to literacy research, the teacher needs to have a clear purpose for read-aloud sessions, in order to reach the full potential for literacy learning (Fisher et al. 2004). In this study, Norwegian first grade teachers do not appear to approach read-alouds with a clear purpose related to literacy learning, except for spontaneously explaining words in the text. Our findings suggest that teachers invite the students to make interpretations on a surface level but not on a deeper level, like language features. We conjecture that this result is integrally connected to how the read-aloud sessions are organized and to ad hoc stops. We argue that ad hoc stops can be valuable to explain words and to respond to students' responses while reading, but ad hoc stops alone are insufficient to create thoughtful and planned literacy instruction. Additionally, spontaneous stops may contribute to a teacher-dominated practice consisting of questioning and quick answers (Teale and Martinez 1996), rather than providing an authentic opportunity for developing oracy skills.

When we consider that the most valuable aspect of readaloud sessions (i.e., the active ingredient for learning) is the talk that surrounds the reading (Beck and McKeown 2001), it is essential to plan stops that invite the students to make reflections within, beyond, and about the text (Fountas and Pinnell 2018). Furthermore, we argue that beyond lunchtime readings, read-aloud sessions should be integrated into school subjects and literacy instruction. If read-aloud sessions were more integrated as part of instruction, teachers would naturally consider the purpose, and would be likely 
to arrange planned stops to accomplish that purpose. Therefore, with greater integration, we believe that teachers would better achieve the potential for literacy development that read-alouds invite.

It is of great concern that the book selections for Norwegian first grade teachers seem to be based on a narrow repertoire with almost no inclusion of informational books. In fact teachers' book selection rationale is somewhat puzzling. While only about one third of teachers reported that content/curricular alignment was "quite important", a high percentage of teachers stated their reason for their last book selection as subject and content related. Therefore, teachers are making an effort to connect read-alouds and content, yet, they do not use factual books. In line with international research (Duke 2000; Smolkin and Donovan 2003), the teachers seemed to neglect informational books as a basis for read-aloud sessions, which is likely due to the nonnarrative structure of these texts. Choosing fictional books can also be part of a school tradition and thereby many teachers feel more comfortable using these texts compared to informational books. This lack of informational texts for read-alouds is of concern for multiple reasons: (a) students show natural interests in informational books (Maloch and Horsey 2013), (b) different types of books give the students access to different type of discourses (e.g. social science) (Valeras and Pappas 2006), and (c) reading informational texts gives students an opportunity for more responses due to the structure of the texts (Smolkin and Donovan 2001). We would challenge Norwegian teachers to question any assumptions that informational texts will not engage and entertain students, and simply try out such texts in their classrooms. Additionally, many historical texts follow narrative/story structures and may be only a minor transition from fiction texts. However, it is important to note that research underlines that teachers have to do more planning to read informational texts (Bingham et al. 2017), which may represent an added challenge for Grade 1 Norwegian teachers.

\section{Recommendations from This Study}

Altogether, we find that Norwegian first grade teacher spend a lot of time on reading aloud, thus creating a great possibility for facilitating literacy development. However, this practice needs to shift in order to reach its full potential. To maintain such a structure, but modify practices, we recommend that teachers should be clearly informed of the benefits of reading aloud, and the ways in which this practice can be integrated as an essential component of literacy instruction. Furthermore, research indicates that expert teachers select appropriate books, establish a clear purpose, practice before reading, have a plan for reading stops, and plan for student contributions (Bingham et al. 2017; Fisher et al. 2004). Referring to the unused potential unveiled in this article; in Norwegian first grade classrooms, sessions seem to be unplanned and not surrounded by rich text talk (Beck and McKeown 2001). To lessen the gap between recommended and current practices we believe that teachers need to be scaffolded or coached in their read-aloud practice. Such scaffolding could consist of examples of how other teachers plan for inter-active read-alouds to support children's encounters with potentially difficult content, text features, or vocabulary (Cummins and Stallmeyer-Gerard 2011; McClure and Fullerton 2017).

Additionally, teachers could be introduced to resources which would help them structure read alouds including, Text Talk (Beck and McKeown 2001) and REAL (Bingham et al. 2017), which capitalize on the role of the read aloud. The instructional cycle of Text Talk (Beck and McKeown 2001) consists of six phases: selection of texts, initial questions, follow-up questions, pictures, background knowledge, and vocabulary, and for each phase, teachers are provided strategies which could enrich the rigor of the read-alouds described within this study. For example, teachers are guided as to how to select complex text in which the construction of meaning relies on the linguistics, rather than simply focusing on the topic. Rather than a reliance on spontaneous questions, teachers develop open and initial questions prompting students to explain the ideas in the text, as well as follow-up questions that are intended to scaffold the student's elaboration of their first responses. Alternatively, REAL (Read and Explore, Ask and Learn) is a framework for how to integrate and connect both storybooks and informational text in read aloud sessions (Bingham et al. 2017). As factual texts have a very limited position in Norwegian first grade teachers read aloud sessions, we find it important to include a program where informational texts also are included. The pairing of informational texts to narratives could build on teachers' current strength of practice. Finally, Jim Trelease's classic (2013), the Read Aloud Handbook, provides highly relevant advice for the first grade teachers in this study, including the importance of selecting across a range of genres and prereading for planning.

\section{Limitations}

This study has several limitations. First, we do not know anything about the quality of teachers' questions and students' responses in the talk that surrounds the reading, as no recordings or observations of how the teachers usually invite the students into texts discussions were made. Secondly, there is a general risk that teachers can over-report in a survey like this. Teachers can both misunderstand questions and/or be sensitive for what they think are the best answers. In this particular study, they may have interpreted the concept of the read-aloud only as the reading of narrative texts, and understood working with words as 
a practice of great value. Regarding the survey design, the placement of open-ended questions after the closed ones may have influenced the open-ended questions. It is possible to believe that the closed questions with different items could have inspired the teachers' answers when they were requested to state a reason for their last book selection. The time of year when the teachers answered the question did, in some parts of the survey, also dominate the results, as shown by the teachers who reported reading a lot of Christmas books when the survey was sent to them in December.

It is important also to note that since this study was embedded within a larger randomized control trial (RCT) regarding the impact of teacher density and professional development on literacy instruction, some of the teachers participated in professional development. Specifically, in 100 of the 150 schools, teachers participated in an online, self-paced professional development approach similar to a professional learning community. Of those, teachers in 53 of the schools chose to work with early literacy materials that might include information about read-alouds. As such, this subset of teachers may have been influenced by their experience.

\section{Conclusion}

This study examined how Norwegian first grade teachers use read-aloud practices, through a survey with both quantitative and qualitative data. The findings in this study are in line with international research underlining that elementary teachers use read-alouds as a daily routine, and that reading aloud can be seen as a form of entertainment (McCaffrey and Hisrich 2017). But to read or not to read is not the only question, as there is no reason to believe that children will not adopt literacy behaviors just because they hear stories. Our pattern of findings (e.g., the reliance on spontaneous stops, not using informational books, and read alouds being unconnected to formal literacy instruction) suggest that the read-aloud practice has much unused potential for literacy learning as it is a frequent practice, but not fully integrated in literacy learning. Because the read-aloud practice already seems to be an integrated part of teachers' daily routines, it would not require too much effort to develop this ongoing practice to fully utilize the potential of read-aloud. The findings in this study also have implications for discussing how to scaffold read-aloud practices among first grade teachers, in order to fully utilize the opportunities for literacy learning that are offered by this practice.
Acknowledgements Open Access funding provided by University of Stavanger.

Open Access This article is licensed under a Creative Commons Attribution 4.0 International License, which permits use, sharing, adaptation, distribution and reproduction in any medium or format, as long as you give appropriate credit to the original author(s) and the source, provide a link to the Creative Commons licence, and indicate if changes were made. The images or other third party material in this article are included in the article's Creative Commons licence, unless indicated otherwise in a credit line to the material. If material is not included in the article's Creative Commons licence and your intended use is not permitted by statutory regulation or exceeds the permitted use, you will need to obtain permission directly from the copyright holder. To view a copy of this licence, visit http://creativecommons.org/licenses/by/4.0/.

\section{References}

Anderson, A., Anderson, J., \& Shapiro, J. (2004). Mathematical discourse in shared storybook reading. Journal for Research in Mathematics Education, 35, 5-33.

Anderson, R. C., Hiebert, E., Scott, J., \& Wilkinson, I. (1985). Becoming a nation of readers: The report of the Commission on Reading. Champaign, IL: Centre for the Study of Reading.

Beck, I., \& McKeown, M. (2001). Text Talk: Capturing the benefits of read-aloud experiences for young children. The Reading Teacher, 55(1), 10-20.

Bernstein, B. (2000 [1996]). Pedagogy, symbolic control and identity: Theory, research, critique. Lanham: Rowman \& Littlefield.

Bingham, G. E., Venuto, N., Carey, M., \& Moore, C. (2017). Making it REAL: Using informational picture books in preschool classrooms. Early Childhood Education Journal, 46, 467-475.

Brabham, E. G., \& Lynch-Brown, C. (2002). Effects of teachers' reading-aloud styles on vocabulary acquisition and comprehension of students in the early elementary grades. Journal of Educational Psychology, 94, 465-473.

Bradley, L. G., \& Donovan, C. A. (2010). Information book readalouds as models for second-grade authors. The Reading Teacher, 64, 246-260.

Bus, A. G., van IJzendoorn, M. H., \& Pellegrini, A. D. (1995). Joint book reading makes for success in learning to read: A metaanalysis on intergenerational transmission of literacy. Review of Educational Research, 65(1), 1-21.

Cazden, C. (1992). Whole language plus: Essays on literacy in the United States and New Zealand. New York: Teachers College Press.

Cummins, S., \& Stallmeyer-Gerard, C. (2011). Teaching for synthesis of informational texts with read-alouds. The Reading Teacher, 64(6), 394-405.

Drogowski, P. P. (2008). Teaching through the year with read-alouds for the primary age. School Library Media Activities Monthly, 24(10), 27-28.

Duke, N. K. (2000). 3.6 minutes per day: The scarcity of informational texts in first grade. Reading Research Quarterly, 35, 202-224.

Fisher, D., Flood, J., Lapp, D., \& Frey, N. (2004). Interactive readalouds: Is there a common set of implementation practices? The Reading Teacher, 58(1), 8-17.

Fountas, I. C., \& Pinnell, G. S. (2018). Every child, every classroom, every day: From vision to action in literacy learning. The Reading Teacher, 72(1), 7-19.

Galda, L., \& Cullinan, B. E. (1991). Literature for literacy: What research says about the benefits of using trade books in the classroom. In J. Flood, J. Jensen, D. Lapp, \& J. Squire (Eds.), 
Handbook of research on teaching the English language arts (pp. 529-535). NY: Macmillan.

Gibbons, P. (2002). Scaffolding language, scaffolding learning. Teaching second language learners in the mainstream classroom. Portsmouth: Heinemann.

Graham, S., Bollinger, A., Booth Olson, C., D'Aoust, C., MacArthur, C., McCutchen, D., \& Olinghouse, N. (2012). Teaching elementary school students to be effective writers: A practice guide (NCEE 2012-4058). Washington, DC: National Center for Education Evaluation and Regional Assistance, Institute of Education Sciences, U.S. Department of Education.

Heath, S. B. (1983). Ways with words. Cambridge: Cambridge University Press.

Heisey, N., \& Kucan, L. (2010). Introducing science concepts to primary students through read-alouds: Interactions and multiple texts make the difference. The Reading Teacher, 63(8), 666-676.

Hooper, M., Mullis, I. V. S., \& Martin, M. O. (2015). PIRLS 2016 context questionnaire framework. In I. V. S. Mullis \& M. O. Martin (Eds.), PIRLS 2016 assessment framework (2nd ed.). Newton, MA: Boston College, TIMSS \& PIRLS International Study Center.

Jobe, R., \& Dayton-Sakari, M. (2002). Info-kids: How to use nonfiction to turn reluctant readers into enthusiastic learners. Markham, ON: Pembroke.

Justice, L. M., \& Ezell, H. K. (2002). Use of storybook reading to increase print awareness in at-risk children. American Journal of Speech-Language Pathology, 11, 17-29.

Kamberelis, G. (1998). Relation between children's literacy diets and genre development: You are writing what you read. Literacy Teaching and Learning, 3(1), 7-53.

Kindle, K. J. (2011). Same book, different experience: A comparison of shared reading in preschool classrooms. Journal of Language and Literacy Education, 7(1), 13-34.

Kraemer, L., McCabe, P., \& Sinatra, R. (2012). The effects of readalouds of expository text on first graders' listening comprehension and book choice. Literacy Research and Instruction, 51(2), $165-178$

Lehman, B. A., Freeman, E. V., \& Allen, V. G. (1994). Children's literature and literacy instruction: "Literature-based" elementary teachers' belief and practices. Reading Horizons, 35(1), 3-29.

Lennox, S. (2013). Interactive read-alouds - an avenue for enhancing children's language for thinking and understanding: A review of recent research. Early Childhood Education Journal, 41, 381-389.

Leung, C. B. (2008). Preschoolers' acquisition of scientific vocabulary through repeated read-aloud events, retellings, and hands-on science activities. Reading Psychology., 29(2), 165-193.

Lickteig, M., \& Russell, J. (1993). Elementary teachers' read-aloud practices. Reading Improvement, 30, 202-208.

Lincoln, Y. S., \& Guba, E. G. (1985). Naturalistic Inquiry. Newbury Park, CA: Sage.

Maloch, B., \& Horsey, M. (2013). Living inquiry: Learning from and about informational texts in a second-grade classroom. The Reading Teacher, 66(6), 475-485.

Mantzicopoulos, P., \& Patrick, H. (2011). Reading picture books and learning science: Engaging young children with informational text. Theory into Practice., 50(4), 269-276.

Marshall, C., \& Rossman, G. B. (2014). Designing qualitative research. Thousand Oaks, CA: Sage.

McCaffrey, M., \& Hisrich, K. (2017). Read-alouds in the classroom: A pilot study of teachers' self-reporting practices. Reading Improvement, 54(3), 93-100.

McClure, E., \& Fullerton, S. K. (2017). Instructional interactions: Supporting students' reading development through interactive readalouds of informational texts. The Reading Teacher, 71(1), 51-59.
Meller, W. B., Richardson, D., \& Hatch, J. A. (2009). Using read alouds with critical literacy literature in K-3 classrooms. Young Children, 64(6), 76-78.

Ministry of Education and Research. (2006). Lareplanverket for Kunnskapsl $\phi$ ftet [The curriculum for the knowledge promotion reform]. Oslo: Ministry of Education and Research. Retrieved from https://www.udir.no/in-english/.

Mol, S. E., Bus, A. G., \& de Jong, M. T. (2009). Interactive book reading in early education: A tool to stimulate print knowledge as well as oral language. Review of Educational Research, 79(2), 979-1007.

Murray, B. A., Stahl, S. A., \& Ivey, G. (1996). Developing phoneme awareness through alphabet books. Reading and Writing: An Interdisciplinary Journal, 8, 307-322.

National Early Literacy Panel. (2008). Developing early literacy: Report of the National Early Literacy Panel. Washington, DC: National Institute for Literacy. https://www.nifl.gov/earlychild hood/NELP/ NELPreport.html.

Nussbaum, M. C. (2010). Not for profit: why democracy needs the humanities. Princeton: Princeton University Press.

Pantaleo, S. (2007). Interthinking: Young children using language to think collectively during interactive read-alouds. Early Childhood Education Journal, 34(6), 439-447.

Pentimonti, J. M., \& Justice, L. M. (2010). Teachers' use of scaffolding strategies during read alouds in the preschool classroom. Early Childhood Education Journal, 37(4), 241-248.

Pentimonti, J. M., Zucker, T. A., \& Justice, L. M. (2011). What are preschool teachers reading in their classrooms? Reading Psychology, 32(3), 197-236.

Powell, R., McIntyre, E., \& Rightmyer, E. (2006). Johnny won't read, and Susie won't either: Reading instruction and student resistance. Journal of Early Childhood Literacy, 6(1), 5-31.

Price, L. H., Bradley, B. A., \& Smith, J. M. (2012). A comparison of preschool teachers' talk during storybook and information book read-alouds. Early Childhood Research Quarterly., 27, 426-440.

Richardson, J. S. (2000). Read it aloud! Using literature in the secondary content classroom. Newark, DE: International Reading Association.

Sandora, C., Santoro, L. E., Baker, S. K., Fien, H., Smith, J. L. M., \& Chard, D. J. (2016). Using read-alouds to help struggling readers access and comprehend complex, informational text. Teaching Exceptional Children, 48(6), 282-292.

Santoro, L. E., Chard, D. J., Howard, L., \& Baker, S. K. (2008). Making the "very" most of classroom read-alouds to promote comprehension and vocabulary. The Reading Teacher, 61(5), 396-408.

Serafini, F., \& Moses, L. (2014). The roles of children's literature in the primary grades. The Reading Teacher, 67(6), 465-468.

Shanahan, T., Callison, K., Carriere, C., Duke, N. K., Pearson, P. D., Schatschneider, C., \& Torgesen, J. (2010). Improving reading comprehension in kindergarten through 3rd grade: A practice guide (NCEE 2010-4038). Washington, DC: National Center for Education Evaluation and Regional Assistance, Institute of Education Sciences, U.S. Department of Education.

Silverman, R., Crandell, J., \& Carlis, L. (2013). Read alouds and beyond: The effects of read aloud extension activities on vocabulary in head start classrooms. Early Education \& Development., $24,98-122$

Smith, F. (1988). Joining the literacy club. Victoria: Abel Press.

Smolkin, L. B., \& Donovan, C. A. (2001). The contexts of comprehension: The information book read aloud, comprehension acquisition, and comprehension instruction in a first-grade classroom. The Elementary School Journal, 102(2), 97-122.

Smolkin, L. B., \& Donovan, C. A. (2003). Supporting comprehension acquisition for emerging and struggling readers: The interactive information book read-aloud. Exceptionality, 11(1), 25-38. 
Snow, C. E., \& Dickinson, D. K. (1991). Skills that aren't basic in a new conception of literacy. In A. Purvis \& T. Jennings (Eds.), Literate systems and individual lives: Perspectives on literacy and schooling (pp. 175-213). Albany: State University of New York Press.

Snow, C. E., \& Ninio, A. (1994). The contracts of literacy: What children learn from learning to read books. In. W. H. Teale, \& Sulzby, E. (Eds.), Emergent literacy: Reading and writing. Norwood, NJ: Ablex Publishing Corporation.

Solheim, O. J., Rege, M., \& McTigue, E. (2017). Study protocol: "Two teachers": A randomized controlled trial investigating individual and complementary effects of teacher-student ratio in literacy instruction and professional development for teachers. International Journal of Educational Research, 86, 122-130.

Stadler, M. A., \& McEvoy, M. A. (2003). The effect of text genre on parent use of joint book reading strategies to promote phonological awareness. Early Childhood Research Quarterly, 18, 502-512.

Stevens, R. J., Van Meter, P., \& Warcholak, N. D. (2010). The effects of explicitly Teaching story structure to primary grade children. Journal of Literacy Research, 42, 159-198.

Strachan, S. L. (2015). Kindergarten students' social studies and literacy learning from interactive read-alouds. Journal of Social Studies Research, 39, 207-233.

Teale, W. H., \& Martinez, M.-G. (1996). Reading aloud to young children: Teachers' reading styles and kindergarteners' text comprehension. In C. Pontecorvo, M. Orsolini, B. Burge, \& L. B. Resnick (Eds.), Children's early text construction (pp. 321-344). Mahwah, NJ: Erlbaum.
Trelease, J. (2013). The read-aloud handbook. New York, NY: Penguin Publishers.

Varelas, M., \& Pappas, C. C. (2006). Intertextuality in read alouds of integrated science-literacy units in urban primary classrooms: Opportunities for the development of thought and language. Cognition and Instruction, 24, 211-259.

Wiseman, A. (2012). Resistance, engagement, and understanding: A profile of a struggling emergent reader responding to read-alouds in a kindergarten classroom. Reading and Writing Quarterly, 28(3), 255-278.

Wright, T. S., \& Gotwals, A. W. (2017). Supporting disciplinary talk from the start of school: teaching students to think and talk like scientists. The Reading Teacher, 71(2), 189-197.

Yopp, R., \& Yopp, H. (2006). Informational texts as read-alouds at school and home. Journal of Literacy Research, 38(1), 37-51.

Yopp, R., \& Yopp, H. (2012). Young children's limited and narrow exposure to informational text. The Reading Teacher, 65(7), $480-490$.

Zucker, T. A., Ward, A. E., \& Justice, L. M. (2009). Print referencing during read-alouds: A technique for increasing emergent readers' print knowledge. The Reading Teacher, 63(1), 62-72.

Publisher's Note Springer Nature remains neutral with regard to jurisdictional claims in published maps and institutional affiliations. 